 \\ z Filologii Polskiej i Słowiańskiej
}

\author{
Teresa Smółkowa \\ (Instytut Języka Polskiego PAN w Krakowie)
}

\section{Języki zachodniosłowiańskie wobec pożyczek angielskich w ostatnim dwudziestoleciu - gramatyka, leksyka, pragmatyka, uwarunkowania społeczno-kulturowe}

W warszawskiej Pracowni Leksykologicznej IJP PAN zespół w składzie: Zbigniew Greń, Krystyna Holly, Bożena Itoya, Teresa Smółkowa, Natalia Urbańczyk-Adach, Anna Żółtak przygotowuje w ramach grantu (NCRH) monografię na temat wpływu pożyczek angielskich na trzy języki zachodniosłowiańskie: czeski, polski, słowacki ${ }^{1}$. Celem niniejszego artykułu jest wyłącznie zasygnalizowanie problemów, jakie zostały uznane za ważne, a więc warte rozważenia $w$ tej monografii. $Z$ tego powodu materiał wyrazowy egzemplifikujący te zagadnienia znajdzie się w monografii.

Jak wiadomo, szczególnie ostatnie dwudziestopięciolecie było okresem zasadniczych przeobrażeń zewnętrznojęzykowych (oświata, kultura) i pozajęzykowych (politycznych, społecznych, ekonomicznych), którym wymienione

1 Kierownikiem grantu jest Teresa Smółkowa, dlatego w artykule poszczególne kwestie są omawiane z punktu widzenia językoznawstwa polonistycznego.

This is an Open Access article distributed under the terms of the Creative Commons Attribution 3.0 PL License (creativecommons.org/licenses/by/3.0/pl/), which permits redistribution, commercial and non-commercial, provided that the article is properly cited. () The Author(s) 2015.

Publisher: Institute of Slavic Studies, PAS \& The Slavic Foundation

[Wydawca: Instytut Slawistyki PAN \& Fundacja Slawistyczna] 
języki musiały sprostać. Zmiany te najpełniej odzwierciedla leksyka, której elementy - leksemy - są znakami językowymi realiów świata pozajęzykowego. Potrzeby nominatywne spowodowały znaczy ilościowy wzrost słownictwa, w tym także anglicyzmów. Zasadnicze pytanie brzmi: w jakim stopniu w każdym z wymienionych języków zachodniosłowiańskich wyzyskano w ostatnich dziesięcioleciach jedno z głównych źródeł pomnażania słownictwa, a mianowicie pożyczki angielskie? Przyjęte w tym opracowaniu granice czasowe są jedynie orientacyjne i wynikają z wiedzy na temat skali zmian, jakie dokonały się w tym czasie w rzeczywistości pozajęzykowej i które wpłynęły na omawiane języki. Nie ustalamy metryk poszczególnych pożyczek w każdym z trzech języków zachodniosłowiańskich, ale dążymy do uzyskania zbioru pożyczek należącego do nowszej i najnowszej warstwy leksykalnej każdego z nich. Warto zauważyć, że ustalenie czasu pojawienia się w tych językach zapożyczeń angielskich, należących do warstwy leksykalnej wyodrębnionej tylko na podstawie kryterium pochodzenia, jest łatwiejsze i bezpieczniejsze niż w wypadku wyrazów należących do innych warstw wyróżnianych w słownictwie (np. potocznej, środowiskowej). Nazywają one bowiem nowe, najczęściej, jak się wydaje, materialne klasy obiektów i zjawiska wcześniej niewystępujące. Wyzyskujemy zatem wiedzę na temat nazywanych przez pożyczki klas obiektów. Weryfikacji wymaga opinia o konserwatyzmie, puryzmie Czechów i Słowaków oraz o znacznym liberalizmie językowym Polaków. Zasadniczym celem monografii będzie ustalenie wpływu zapożyczeń angielskich na różne podsystemy językowe (z wyjątkiem składniowego) każdego z wymienionych języków zachodniosłowiańskich.

W polskiej literaturze językoznawczej istnieje niewiele opracowań poświęconych prezentacji zasobów pożyczek angielskich w języku polskim i procesowi ich ilościowego wzrostu ${ }^{2}$. Przed wojną odnotowano 531 takich zapożyczeń, do roku 1961 zarejestrowano ponad 700 anglicyzmów, do roku 1986 - 1000, do roku 2000 - 2000 (Mańczak-Wohlfeld, 2010, s. 9). Andrzej Markowski pisze: „W niniejszych uwagach skupię się tylko na najnowszych zapożyczeniach, tych, które w polszczyźnie mediów pojawiły się w ciągu ostatniego ćwierćwiecza XX wieku” i „Łącznie można mówić o mniej więcej pięciuset nowych, zapożyczonych elementach leksykalnych" (Markowski, 2000, ss. 97, 106) Z porównania przytoczonych wyżej danych ilościowych (według Elżbiety Mańczak-Wohlfeld

${ }^{2} \mathrm{~W}$ artykule podaję jedynie podstawowe opracowania w języku polskim. Literatura przedmiotu dotycząca zapożyczeń angielskich w trzech omawianych językach znajdzie się w monografii. 
w latach 1986-2000 pojawiło się 1000 nowych pożyczek angielskich, według Andrzeja Markowskiego w latach 1975-2000 około 500 nowych pożyczek, przede wszystkim - ale nie tylko - angielskich) wynika, że ustalenie liczebności pożyczek angielskich nie jest łatwe i zależy chyba głównie od rodzaju i liczby wyzyskanych źródeł materiałowych. Różnice ilościowe są jednak na tyle duże, że należałoby je wyjaśnić bardziej szczegółowo ${ }^{3}$.

Najobszerniejszy zbiór pożyczek angielskich w języku polskim zawiera Słownik zapożyczeń angielskich w polszczyźnie, którego redaktorem naukowym i merytorycznym jest Elżbieta Mańczak-Wohlfeld (Mańczak-Wohlfeld, 2010). W części O słowniku badaczka podaje podstawowe informacje na temat zawartego w nim materiału:

1. Pochodzi on $\mathrm{z}$ trzech słowników PWN - dwóch słowników wyrazów obcych $(1995,2003)$, Uniwersalnego słownika jezzyka polskiego oraz nowych zapożyczeń wybranych z Korpusu Języka Polskiego PWN i najnowszych, które zostały użyte $\mathrm{w}$ mass mediach i w internecie;

2. Obejmuje wyrazy należące do standardowej polszczyzny, a pomija te, które należą do odmian specjalistycznych;

3. Nie jest liczny (około 2000 haseł), ale składa się z leksemów często występujących w tekstach;

4. Wypełnia 45 „pól semantycznych, np. sport (najliczniejsze), muzyka, morze, reklama, narkotyki, praca";

5. Obejmuje wyłącznie pożyczki angielskie, które przedostały się do języka polskiego za pośrednictwem angielszczyzny (Mańczak-Wohlfeld, 2010, ss. 10, 12).

Znaczenia omawianego słownika jako najobszerniejszego zbioru anglicyzmów w polszczyźnie nie sposób przecenić. Niemniej wykorzystanie w pełni zgromadzonego w nim materiału dla naszych celów nie jest, niestety, możliwe i to $\mathrm{z}$ kilku powodów. W wykazie skrótów i symboli znajdziemy następujące: arch., daw., przestarz. świadczące o tym, że w słowniku znajduje się grupa wyrazów nieużywanych nie tylko w dwóch, trzech ostatnich dziesięcioleciach, lecz także współcześnie, przy czym współczesność oznacza tu okres powojenny, w którym odnotowuje się początkowo wolniejszy, a po roku 1989 coraz szybszy ilościowy wzrost anglicyzmów w polszczyźnie. W uwagach

\footnotetext{
${ }^{3}$ Być może odpowiedź - przynajmniej częściową - przyniesie planowana monografia.
} 
O słowniku Elżbieta Mańczak-Wohlfeld stwierdza, że - jak wspomniano wyżej - uwzględnione w nim wyrazy występują w 45 polach semantycznych, tymczasem w wykazie stosowanych w nim skrótów znajduje się ok. 70 kwalifikatorów zwanych dziedzinowymi. Materiał do tego słownika pochodzi jednak, z wyjątkiem Korpusu PWN, ze słowników, w których kwalifikatory tech., chem., fiz. są traktowane jako specjalistyczne. Zamieszczone w słowniku przykłady, takie jak np. bruceloza wet., gawial zool., genocide socj., henr fiz., kwantyl mat., ley lines okult., flexicurity ekon., lorens chem., szybolet, slab techn., ryboza biochem., regolit geol., świadczą o tym, że jakaś część słownictwa zawartego w tym słowniku nie należy jednak do standardowej polszczyzny. Wprawdzie za cechę charakterystyczną współczesnej leksyki polskiej uznaje się jej niewątpliwie ciągle narastającą terminologizację, co utrudnia rozróżnienie warstwy specjalistycznej od pozostałych, niemniej przytoczone przykłady trudno uznać za należące do leksemów standardowych. W materiale zawartym w omawianym słowniku znaleźć można także wyrazy nazywające realia w ogóle w Polsce nieznane, np. rotang, shire, skwater, stout itd. Wątpliwe też, aby wskazane wyżej grupy wyrazów często występowały w tekstach niespecjalistycznych, a nawet popularno-naukowych.

Ważne jest również następujące założenie przyjęte w Słowniku zapożyczeń angielskich $w$ polszczyźnie: „[...] bierzemy pod uwagę jedynie ostatnie źródła kontaktu językowego. $Z$ tego powodu wyrazy angielskie, które przedostały się przez medium języka niemieckiego, francuskiego czy rosyjskiego, nie są traktowane tu jako anglicyzmy" (Mańczak-Wohlfeld, 2010, s. 10). Wynika stąd, że w omawianym słowniku kryterium decydującym o uznaniu wyrazu za pożyczkę angielską w polszczyźnie jest przejęcie tego wyrazu bezpośrednio z języka angielskiego. Takie jest również stanowisko większości badaczy zajmujących się pożyczkami, choć niektórzy za pożyczkę z danego języka uznają wyraz z rdzeniem, który z niego pochodzi. Każde ze stanowisk ma swoje uzasadnienie $i$ jest w polskich pracach lingwistycznych reprezentowane ${ }^{4}$.

${ }^{4}$ Według Bogdana Walczaka pożyczką w języku polskim jest leksem, bez względu na jego pochodzenie, który polszczyzna przejęła bezpośrednio z danego języka (Walczak, 1982). Podobne stanowisko zajmuje Małgorzata Witaszek-Samborska w bardzo wartościowej, przynoszącej wiele informacji pracy Wyrazy obcego pochodzenia we współczesnej polszczyźnie (Witaszek-Samborska, 1992). Inne stanowisko zajmują np. Jacek Fisiak (1961) czy Małgorzata Milewska (1982), zdaniem których o pochodzeniu zapożyczenia decyduje jego etymologia. 
W konsekwencji za zapożyczone za pośrednictwem języka angielskiego a więc za anglicyzmy w języku polskim - są uznawane następujące leksemy: chapoti, chop suey, chutney, czau-czau, igloo, jo-jo, koh-i-noor, liczi, shar pei. Wyrazy sklasyfikowane jako pożyczki angielskie tylko na podstawie bezpośredniej drogi zapożyczenia trudno jednak uważać za mające bezpośredni wpływ na język polski.

Powyższe uwagi w niczym nie umniejszają znaczenia Słownika zapożyczeń angielskich $w$ polszczyźnie. Ich cel stanowi jedynie zwrócenie uwagi na stopień trudności wiążących się z ustaleniem zasobu pożyczek w językach zachodniosłowiańskich. Wynikają one głównie z kilku powodów:

- braku ustaleń dotyczących statusu w leksyce wyrazów będących terminami i występujących w tekstach nienaukowych;

- problemów związanych z ustaleniem drogi zapożyczeń - bezpośrednio $z$ języka angielskiego czy przez medium innego języka - a nawet etymologii części z nich;

- praktycznych trudności z jednoznacznym zakwalifikowaniem konkretnych pożyczek do którejś z wyróżnianych warstw słownictwa, zważywszy na liczebność, a zwłaszcza tempo zmian zachodzących w leksyce.

Omawiany słownik będzie wyzyskany jako ważne i bardzo pomocne źródło materiału po dokładnej analizie jego zawartości i porównaniu z własnym, bogatym zbiorem stanowiącym główną materiałową podstawę monografii w części poświęconej językowi polskiemu.

Przyjmuje się w niej następujące założenia. Za pożyczki angielskie uznaje się wyrazy etymologicznie angielskie. Ich pochodzenie w języku polskim ustala się głównie na podstawie Wielkiego słownika angielsko-polskiego PWN-Oxford (Lewandowska-Tomaszczyk, 2002) oraz innych nowszych słowników wyrazów obcych. Ustalenie pochodzenia pożyczek komplikuje istnienie słownikowej ligi amerykańsko-zachodnioeuropejskiej. ${ }^{5}$. Fakt uwzględnienia w materiale pożyczek angielskich, które znalazły się $w$ tekstach prasowych, rzadziej $w$ internecie, nie przesądza o ich przynależności do którejś z odmian stylowych ani - tym bardziej - do leksyki znanej użytkownikowi języka. W prasie wysokonakładowej czytelnicy stykają się z pożyczkami angielskimi w różnych typach tekstów, ale to nie znaczy, że stają się one elementami ich zasobu czynnego, a nawet biernego. Można przyjąć, że o znajomości pożyczek decydują przede wszystkim

\footnotetext{
${ }^{5}$ O lidze słownikowej pisze m.in. Jolanta Maćkiewicz (Maćkiewicz, 2001).
} 
indywidualne zainteresowania. Przynależność zapożyczeń do którejś z warstw słownictwa ustala się na podstawie kontekstów, stopień ich upowszechnienia zaś - na podstawie częstotliwości występowania w elektronicznej bazie danych i w internecie. Pożyczka często używana ma szansę upowszechnić się i stać się elementem leksyki standardowej, dlatego konieczny będzie podział pożyczek angielskich na częste w tekstach i na mające w nich niewielką frekwencję. Za podstawowe kryterium leksykalnej klasyfikacji pożyczek przyjmuje się kryterium onomazjologiczne, o którym więcej piszę w dalszej części artykułu.

Jak już wspomniałam, cel naukowy projektu stanowi ustalenie rodzajów i zakresu zmian, jakie zaszły w języku czeskim, polskim i słowackim pod wpływem pożyczek angielskich w ostatnich dziesięcioleciach. Dla osiągnięcia tego celu konieczne jest zebranie materiału wyrazowego nie tyle pełnego, bo to odrębne, niełatwe zadanie wobec szybkiego tempa zmian w leksyce, ile bogatego i różnorodnego. Tak więc nie kompletny zasób pożyczek angielskich w językach czeskim, polskim i słowackim, ale przede wszystkim prawidłowe ustalenie ich pochodzenia umożliwią realizację założonych celów szczegółowych. W projekcie zakłada się ograniczenie zasobu tych pożyczek do haseł nieterminologicznych znajdujących się, w przypadku języka polskiego, głównie we własnej, ciągle uzupełnianej bazie danych obejmującej leksemy wyekscerpowane z tekstów prasowych, rzadko z innych źródeł mających różny charakter, a więc do wyrazów o znacznym zasięgu społecznym (prasa, internet).

Przedmiotem szczegółowych badań będzie przede wszystkim wpływ pożyczek na podsystemy: fonologiczny, morfologiczny i leksykalny.

1. W języku angielskim występują fonemy i ich połączenia, których brak lub które są rzadkie w językach słowiańskich. Istotne w tej sytuacji jest ustalenie, czy połączenia te wywarły wpływ na omawiane języki, zwłaszcza w zakresie połączeń śródwyrazowych (np. w języku polskim niesamodzielnych artykulacyjnie $\left.s^{\prime} i, t^{\prime} i, s^{\prime} i, c^{\prime} i\right)$.

2. W językach zachodniosłowiańskich podsystem fleksyjny odgrywa zasadniczą rolę w przyswajaniu pożyczek. Na przykład w języku polskim odmianę według rodzimych paradygmatów uznaje się za początkowy etap polonizacji, co jest zrozumiałe, zważywszy, że w językach fleksyjnych, do których należą wszystkie języki zachodniosłowiańskie, końcówki fleksyjne decydują o funkcjach składniowych wyrazów. Język angielski, jak wiadomo, należy do grupy języków pozycyjnych, w których szyk, pozycja wyrazu w wypowiedzeniu wyznacza jego funkcję syntaktyczną. Włączenie anglicyzmów do 
systemu przypadkowego fleksyjnych języków zachodniosłowiańskich, jeżeli nie warunkuje, to niewątpliwie co najmniej usprawnia komunikację językową, której podstawową jednostką jest wypowiedzenie. Badania powinny przynieść odpowiedź na pytanie, czy języki czeski i słowacki przyswajają pożyczki w podobny sposób, jak czyni to język polski. Z ich odmianą w językach zapożyczających wiąże się zwłaszcza problem ustalenia roli kryterium fonetycznego, a więc cech fonetycznych wygłosu decydującego o zastosowaniu określonego paradygmatu. W tym zakresie można się spodziewać znacznego stopnia regularności w poszczególnych językach. Sprawdzenia wymagają jednak sposoby adaptacji w odniesieniu do konkretnych kategorii gramatycznych, fleksyjnych oraz selektywnej (klasyfikującej) kategorii rodzaju.

Odmienność leksemów to, jak wskazano wyżej, cecha definicyjna języków fleksyjnych. Nie dziwi więc, że grupa leksemów nieodmiennych jest w nich jak dotąd - nieliczna. Ważnym zadaniem badawczym będzie sprawdzenie, czy pożyczki angielskie powiększają grupę leksemów nieodmiennych, a zwłaszcza jaka jest skala tego zjawiska w językach zachodniosłowiańskich. Przyczyny nieodmienności mogą być różne: występowanie w wygłosie głoski nietypowej dla M. l. poj. (w języku polskim np. -y), utrudniającej wybór wzorca, częste występowanie alternacji zawsze zmieniającej materialną formę leksemów, różnice pomiędzy pisownią a wymową wyrazów angielskich. Dokładne ustalenie przyczyn nieodmienności anglicyzmów w analizowanych językach przyniesie także informacje o funkcjonowaniu reguł w nich obowiązujących. Punktem wyjścia analizy fleksyjnej będzie podział zgromadzonych pożyczek z punktu widzenia funkcjonalnego, a więc na części mowy.

3. Bardzo ważnym zadaniem w proponowanym projekcie będzie określenie udziału podsystemu słowotwórczego w procesie adaptacji pożyczek w omawianych językach, zwłaszcza wobec formułowanego - np. przez niektórych polskich badaczy - twierdzenia o jego niewielkiej roli we współczesnej polszczyźnie. Nawet jeżeli istotnie możliwości tego podsystemu są obecnie rzadko wyzyskiwanym sposobem pomnażania leksyki, polegającym na łączeniu jego elementów z rodzimymi morfemami rdzennymi, to znaczny udział morfemów słowotwórczych w procesie adaptacji pożyczek nie ulega wątpliwości. W wyniku naszych badań może okazać się, że pożyczki, paradoksalnie, uaktywniły działanie systemów słowotwórczych omawianych języków. Badania te pozwolą także, co szczególnie ważne, na określenie stopnia produktywności poszczególnych formantów występujących w analizowanym zasobie przyswojonych pożyczek. Otwarte pozostaje także pytanie o poszerzenie inwentarza morfemów słowotwórczych 
pod wpływem pożyczek, przy czym za nowy proponujemy uznać tylko taki morfem, który łączy się z rodzimymi morfemami rdzennymi (np. w języku polskim -ing). Zbadania wymaga również stopień wariantywności morfemów słowotwórczych. Wariantywność może bowiem okazać się istotnym etapem wstępnym i nieodłącznym zjawiskiem towarzyszącym procesom adaptacyjnym pożyczek angielskich, zważywszy na ich znaczny napływ w krótkim czasie.

4. W zakresie leksyki badania obejmą głównie zapożyczenia tzw. właściwe o różnym stopniu przyswojenia oraz hybrydy. W badaniach komparatystycznych trzech języków szczególnie użyteczna jest klasyfikacja pożyczek na pola tematyczne - zwane też polami semantycznymi lub pojęciowymi - pozwalająca ustalić, w jakich polach występują pożyczki, jaka jest liczebność pożyczek w każdym z wyodrębnionych pól, jakie są proporcje między nowszymi pożyczkami a zawartością leksykalną danego pola. Innymi słowy - w jakim stopniu pożyczki wzbogacają każde $\mathrm{z}$ wyodrębnionych pól. Klasyfikacja materiału wyrazowego na podstawie kryterium onomazjologicznego pozwala najpełniej ukazać związek języka z rzeczywistością pozajęzykową i umożliwia pełną porównywalność różnych języków. W badaniach konfrontatywnych właśnie takie kryterium jest najbardziej przydatne. Bardzo prawdopodobne różnice między językami zachodniosłowiańskimi w rodzaju i liczbie pól tematycznych, dających się wyodrębnić w anglicyzmach w każdym $\mathrm{z}$ nich, będą rezultatem różnic w kontekstach społecznych i kulturowych tych języków. Poza dokładnym ustaleniem zawartości poszczególnych pól, warto by także - w miarę możliwości - pokusić się o próbę ustalenia pozycji poszczególnych pożyczek w obrębie pola - centralnej lub peryferycznej - jak również obecności w nich gniazd leksykalno-słowotwórczych.

5. Wiadomo, że rozwój leksyki jest nierównomierny, podobnie wygląda kwestia zapożyczeń, które w różnym stopniu zasilają poszczególne warstwy słownictwa: ogólną, erudycyjną, potoczną, środowiskową. Dokładnego zbadania wymaga występowanie pożyczek angielskich w obrębie leksyki potocznej, która - z racji pełnionej funkcji w komunikacji językowej - powinna być na nie najbardziej odporna jako warstwa używana w sytuacjach nieoficjalnych, a zwłaszcza warstwa zawierająca słownictwo nacechowane, ekspresywne. Jednym ze źródeł pożyczek angielskich w odmianie potocznej może być dynamicznie rozwijająca się leksyka środowiskowa. Zważywszy na nieostrość granic między wymienionymi warstwami oraz dynamizm leksemów, w tym także jak wolno przypuszczać - pożyczek, nie sposób dokładnie, bez ryzyka błędu, 
umiejscowić ich w obrębie wyróżnionych warstw, ale próba przeprowadzenia takiej klasyfikacji jest konieczna.

6. W analizie pożyczek angielskich należy także uwzględnić zjawisko homonimii i synonimii oraz polisemii rozpatrywane w relacji: a) nowsze pożyczki w stosunku do już funkcjonujących leksemów; b) nowsze pożyczki w obrębie tylko nowego zasobu (co jest zapewne rzadkim zjawiskiem). W tym wypadku porównanie trzech języków zachodniosłowiańskich może przynieść ciekawe rezultaty, ponieważ działanie podobnych czynników - zwłaszcza pozajęzykowych - nie musi wywoływać podobnych zmian. Szczególnie interesujące wyniki powinno przynieść porównanie liczby i zawartości informacyjnej składników znaczenia takich samych pożyczek występujących w każdym z trzech lub choćby tylko z dwóch języków. Jak wiadomo, każda pożyczka to nazwa jakiegoś elementu rzeczywistości pozajęzykowej, będąca jej językowym znakiem mającym formę i treść. Czy w procesie przyswajania obcych leksemów pożyczamy i materialną formę i treść, czy też - znając odniesienie przedmiotowe - składniki znaczenia ustalamy na gruncie własnego języka? W tym ostatnim wypadku różnice w rodzaju, liczbie i hierarchii składników treści dowodziłyby decydującej roli odniesienia przedmiotowego w krystalizacji znaczenia przyswajanych pożyczek. Ponadto różnice te przyniosłyby informacje o sposobie widzenia danej klasy obiektów zależnym zarówno od języka, jak i od kultury. Brak takich różnic byłby równoznaczny z postępującą unifikacją języków także na płaszczyźnie semantycznej. Otwarte pozostaje pytanie, czy i w jakim stopniu pożyczki powiększają zasób leksemów całkowicie arbitralnych oraz neutralnych, nienacechowanych. Odrębnym, istotnym zagadnieniem jest uwzględnienie również rozwoju znaczeniowego pożyczek w każdym z języków, stopień ich polisemiczności mający swe źródło w sferze asocjacyjnej wielu z nich. W typologicznej klasyfikacji języków jednym z kryteriów w zakresie leksyki są proporcje między leksemami konkretnymi i abstrakcyjnymi, wśród których można wyodrębnić różne poziomy abstrakcji. W tym wypadku chyba nie należy spodziewać się większych różnic między językami zachodniosłowiańskimi.

7. Ze względu na to, że teksty prasowe, będące głównym źródłem polskiego materiału wyrazowego, są zróżnicowane pod względem stylu, w opracowaniu można będzie uwzględnić pragmatyczny aspekt pożyczek. Odnosi się on do różnych sposobów użycia pożyczek w wypowiedziach, a zatem do kompetencji komunikacyjnej i - w pewnym stopniu - także kulturowej użytkowników języka. A priori można przypisać pożyczkom pełnienie w tekstach funkcji informatywnej. Natomiast funkcję ekspresywną pożyczek angielskich można będzie ustalić 
na podstawie ich treści (semów), jak również struktury w języku zapożyczającym - tu różnice między badanymi językami mogą być znaczne, ponieważ poza kulturowym i społecznym ważny jest także w tym wypadku kontekst psychologiczny komunikacji językowej. On właśnie ma decydujący wpływ na użycie pożyczek pod wpływem mody językowej. Dzieje się tak wtedy, kiedy pożyczki dublują rodzime leksemy, są więc elementami redundantnymi. Ustalenie stopnia redundancji pożyczek angielskich w badanych językach zachodniosłowiańskich jest jednym z ważniejszych celów badawczych projektu.

8. Jak wiadomo, najbardziej skodyfikowana jest norma ortograficzna, do niedawna restrykcyjna i jednoznacznie ustalająca pisownię wyrazów. W wydanych ostatnio słownikach języka polskiego w główce artykułu hasłowego podaje się warianty ortograficzne niektórych pożyczek, świadczące o braku ich jednolitej notacji w tekstach pisanych. Wariantywność ortograficzna pożyczek angielskich jest uderzającą cechą tej grupy wyrazów. Można wskazać dwie główne przyczyny takiego stanu rzeczy - duża liczba anglicyzmów i znaczne tempo ich napływu w stosunkowo krótkim czasie. Dzięki środkom technicznym pożyczki mogą się błyskawicznie upowszechniać. Wszystko to sprawia, że utrudnione jest ustalanie obowiązujących reguł ortograficznych. Zebrany materiał pozwoli na ustalenie zakresu tego zjawiska w każdym z trzech języków zachodniosłowiańskich. Istotne w tym względzie będzie również uwzględnienie różnic w tradycji stanowienia norm ortograficznych w tych językach i wpływ tradycji na procesy adaptacyjne oraz na ustalenia normatywne w odniesieniu do anglicyzmów.

9. Ważne będzie także rozważenie różnych aspektów funkcjonowania anglicyzmów w zmienionym i ciągle zmieniającym się kontekście społecznym i kulturowym. Przez społeczny kontekst funkcjonowania języka rozumiem wszelkie społeczne okoliczności wpływające na zmiany w nim zachodzące lub warunkujące powstawanie i cechy językowe niektórych jego odmian - w tym wypadku zwłaszcza socjolektów. Pozycja języka angielskiego, uznawanego za język międzynarodowy, przesądza o jego powszechnym wyborze w szkołach. Młodzi ludzie - niezależnie od rzeczywistej znajomości tego języka - są z nim coraz bardziej osłuchani, co sprzyja szybkiemu upowszechnianiu się pożyczek angielskich i ich łatwemu utrwalaniu się w leksyce. Z kolei mówiąc o zmienności kontekstu kulturowego mam na uwadze przede wszystkim rozszerzający się zasięg czy wręcz dominację kultury masowej, a także nieprzerwanie utrzymującą się w omawianym okresie ostatnich dwudziestu kilku lat atrakcyjność kultury angloamerykańskiej, która powoduje ciągły napływ pożyczek angielskich. 
Wyniki badań zostaną przedstawione w postaci obszernej publikacji zbiorowej mającej charakter monografii. Szczegółowe zadania badawcze wskazane w punktach 1-9 zostaną opracowane na podstawie obszernego materiału wyrazowego w kilku rozdziałach. Każdy rozdział powstanie w oparciu o trzyczęściową strukturę. W jego części pierwszej prezentacja osiągniętych wyników zostanie przedstawiona oddzielnie dla języka czeskiego, polskiego i słowackiego. W drugiej części znajdą się informacje wynikające $z$ porównania tych języków w procesie adaptacji pożyczek angielskich w zakresie podobieństw i różnic między nimi. W trzeciej części zawarte będzie wyjaśnienie przyczyn językowych i pozajęzykowych podobieństw i różnic. Przy wyjaśnianiu różnic nie przyjmuje się żadnych ograniczeń, ponieważ ich powody mogą mieć różną naturę, niedającą się obecnie przewidzieć. Jak widać, ujęcie konfrontatywne będzie zarazem podstawą metodologiczną i celem prowadzonych badań. Jednolita struktura kolejnych rozdziałów monografii poświęconej rezultatom oddziaływania pożyczek angielskich na trzy różne języki i na kilka podsystemów tych języków ułatwi przedstawianie wyników badań w sposób możliwie najpełniejszy i w pełni porównywalny. Objętość poszczególnych rozdziałów będzie zależała od stopnia trudności związanych $\mathrm{z}$ analizą rozpatrywanych $\mathrm{w}$ nich zagadnień. Niewątpliwie najobszerniejszy i wymagający dużego nakładu pracy będzie rozdział poświęcony pożyczkom rozpatrywanym w obrębie leksykologii wewnętrznej (semantyka) i zewnętrznej (głównie socjoleksykologia). Z ustaleniem składników znaczenia pożyczek oraz ich relacji z innymi leksemami wiążą się komplikacje natury teoretycznej, a także praktycznej ze względu na konieczność uwzględnienia trzech języków w ujęciu porównawczym. Z kolei klasyfikacja pożyczek na pola tematyczne wymaga uwzględnienia najszerzej rozumianego kontekstu kulturowego, jak również także politycznego, społecznego i gospodarczego. Zmiany w tych obszarach nie przebiegały stopniowo, ale zaszły nagle i najpełniej ujawniły się w zawartości pól tematycznych. Na ich przykładzie aspekt kulturowy badań lingwistycznych uwidacznia się bardzo wyraziście. Badania pożyczek angielskich ukażą zdolności adaptacyjne trzech głównych języków słowiańskich i sposób pełnienia przez anglicyzmy funkcji znakowej w każdym z nich ${ }^{6}$.

${ }^{6}$ Problemy poruszone wyżej w punktach 1-9 są omówione z różnym stopniem szczegółowości przez wielu autorów w bardzo licznych publikacjach poświęconych zapożyczeniom. Bibliografia tych prac zostanie przedstawiona w monografii. 


\section{Bibliografia}

Bogusławska, E. (1994). Adaptacja fonetyczna i graficzna pożyczek angielskich w języku polskim i czeskim. Poradnik Językowy, (8), 1-15.

Fisiak, J. (1961). Zapożyczenia angielskie w języku polskim: analiza interferencji leksykalnej. (Nieopublikowana praca doktorska). Łódź.

Lewandowska-Tomaszczyk, B. (Red.) (2002). Wielki słownik angielsko-polski PWN-Oxford. Warszawa: Wydawnictwo Naukowe PWN, Oxford: Oxford University Press.

Maćkiewicz, J. (2001). Wyrazy międzynarodowe (internacjonalizmy) we współczesnym języku polskim. W J. Bartmiński, Współczesny język polski (ss. 555-561). Lublin: Wydawnictwo Uniwersytetu Marii Curie-Skłodowskiej.

Mańczak-Wohlfeld, E. (1995). Tendencje rozwojowe współczesnych zapożyczeń angielskich w języku polskim. Kraków: Universitas.

Mańczak-Wohlfeld, E. (2004). Fonetyka zapożyczeń angielskich w polszczyźnie XXI wieku. Poradnik Językowy, (3), 3-7.

Mańczak-Wohlfeld, E. (Red.) (2010). Słownik zapożyczeń angielskich w polszczyźnie. Warszawa: Wydawnictwo Naukowe PWN.

Markowski, A. (2000). Jawne i ukryte nowsze zapożyczenia leksykalne w mediach. W J. Bralczyk \& K. Mosiołek-Kłosińska (Red.), Język w mediach masowych (ss. 96-111). Warszawa: Upowszechnianie Nauki - Oświata „UN-O”.

Milewska, M. (1982). Wyrazy hiszpańskie w języku polskim. Poradnik Językowy, (2), 89-98.

Sękowska, E. (2007). Wpływ języka angielskiego na słownictwo polszczyzny ogólnej. Poradnik Językowy, (5), 44-53.

Walczak, B. (1982). Z zagadnień etymologizacji zapożyczeń romańskich w języku polskim. W J. Tokarski (Red.), Język. Teoria-Dydaktyka: materiały V Konferencji Młodych Językoznawców-Dydaktyków, Nowa Wieś Szlachecka, 16-17 maja 1980 r. (ss. 172-194). Kielce: Wyższa Szkoła Pedagogiczna im. Jana Kochanowskiego.

Waszakowa, K. (2002). Współczesne słownictwo polskie i czeskie wobec ekspansji zapożyczeń. Poradnik Językowy, (8), 3-18.

Waszakowa, K. (2007). Internacjonalizacja współczesnej polszczyzny - szansa czy zagrożenie?. Przegląd Humanistyczny, (1), 219-228.

Witaszek-Samborska, M. (1992). Wyrazy obcego pochodzenia we współczesnej polszczyźnie. Poznań: Wydawnictwo Nakom.

Zdunkiewicz-Jedynak, D. (2008). Spolszczony angielski czy zangielszczony polski? Wpływ języka angielskiego na język generacji gadu-gadu. Poradnik Językowy, (3), 50-61. 


\section{West Slavic languages and English loanwords in the last two decades - an overview of grammar, lexicon, pragmatics and the socio-cultural context}

\section{Summary}

The recent decades, as is generally acknowledged, have been a period of profound changes in Central and Eastern Europe. These changes are reflected in the lexicon. Nominative needs have caused a remarkable vocabulary growth, with loanwords constituting a numerous and still growing group. The main research goal of the authors of the monograph project introduced in this article is to look into the influence of the English language upon West Slavic languages. The effect of Anglicisms on the phonetic, morphological and lexical subsystems will be subject to an in-depth examination. Of particular importance will be the adaptative processes affecting these loanwords in Czech, Polish and Slovak. The authors will also take into account the pragmatic aspect of borrowings as well as their functioning in the social and cultural context. This contrastive approach will make it possible to indicate similarities and differences in the process of assimilating English borrowings into West Slavic languages.

\section{Języki zachodniosłowiańskie wobec pożyczek angielskich w ostatnim dwudziestoleciu - gramatyka, leksyka, pragmatyka, uwarunkowania społeczno-kulturowe}

\section{Streszczenie}

Artykuł jest poświęcony omówieniu planowanej monografii na temat nowszych i najnowszych pożyczek angielskich w językach: czeskim, polskim i słowackim. 
Ostatnie dziesięciolecia były, jak wiadomo, okresem zasadniczych zmian w Europie środkowo-wschodniej. Zmiany te odzwierciedla leksyka. Potrzeby nominatywne spowodowały ilościowy wzrost słownictwa, w którym odrębną grupę - liczną i ciągle rosnącą - stanowią pożyczki. Zasadniczym celem badawczym autorów monografii jest odpowiedź na pytanie, jaki jest wpływ języka angielskiego na języki zachodniosłowiańskie. Przedmiotem szczegółowych rozważań będzie oddziaływanie anglicyzmów na podsystemy fonetyczny, morfologiczny, leksykalny. Za ważne uznaje się zwłaszcza prześledzenie procesów adaptacyjnych tych pożyczek w języku czeskim, polskim i słowackim. Autorzy uwzględnią także aspekt pragmatyczny zapożyczeń oraz ich funkcjonowanie w kontekście społecznym i kulturowym. Ujęcie konfrontatywne umożliwi wskazanie podobieństw lub różnic w procesie przyswajania przez języki zachodniosłowiańskie pożyczek angielskich.

Keywords: Anglicisms; west Slavic languages; phonology; morphology; lexicon; culture

Słowa klucze: anglicyzmy; języki zachodniosłowiańskie; fonologia; morfologia; leksyka; kultura

\footnotetext{
Teresa Smółkowa,Institute of the Polish Language of the Polish Academy of Sciences, Cracow Correspondence: ijp@ijp-pan.krakow.pl

The work has been prepared at author's own expense.

Competing interests: no competing interests have been declared.
} 